CESIS Electronic Working Paper Series

Paper No. 405

\title{
Regulation, firm dynamics and entrepreneurship
}

\author{
Pontus Braunerhjelm \\ Sameeksha Desai \\ Johan E. Eklund
}

May, 2015 


\title{
REGULATION, FIRM DYNAMICS AND ENTREPRENEURSHIP
}

Pontus Braunerhjelm, Sameeksha Desai and Johan E. Eklund

13 February 2015

\author{
Pontus Braunerhjelm \\ Swedish Entrepreneurship Forum and Royal Institute of Technology \\ Address: Grevgatan 34, $3^{\text {rd }}$ floor, Stockholm, SE-11453, Sweden \\ Email: pontus.braunerhjelm@entreprenorskapsforum.se
}

Phone: +46.70 .932 .0189$

\author{
Sameeksha Desai \\ Indiana University \\ Address: 1315 E. $10^{\text {th }}$ Street, Bloomington IN, 47405, USA \\ Email: desai@indiana.edu \\ Phone: +001.812.855.5615
}

\section{Johan Eklund * corresponding author}

Swedish Entrepreneurship Forum and Jönköping International Business School Address: Grevgatan 34, $3^{\text {rd }}$ floor, Stockholm, SE-11453, Sweden

Email: johan.eklund@entreprenorskapsforum.se

Phone: +46.706.591.406

\begin{abstract}
Entrepreneurship can have important positive effects linked to job creation, wealth and income generation, innovation and industry competitiveness. Scholars and policy-makers around the world have turned to the regulatory environment as a mechanism through which entrepreneurship can be encouraged, grown and its economic benefits harnessed. The effect of regulatory conditions on entrepreneurship however is not well understood, and can be nuanced given the wide range of regulatory tools and possible areas of impact. This paper serves as the introduction to a special issue, which seeks to shed some light on the relationship between regulation, firm dynamics and entrepreneurship. We identify some foundational considerations relevant to this relationship and discuss key questions, followed by a brief overview of each of the papers contained in the special issue.
\end{abstract}

Keywords: entrepreneurship, regulation, firm, entry

JEL-codes: K20, L30, L51, M13.

Acknowledgments: Valuable research support is acknowledged from the Marianne and Marcus Wallenberg Foundation and Vinnova. 


\section{Introduction}

Economic regulations typically refer to constraints, often codified in law, on the behaviour of agents in the market place, which are enforced by courts or administrative agencies ${ }^{1}$. Regulation can be designed to motivate or deter a range of economic outcomes. For example, cutting "red tape" is currently a favoured governmental strategy in creating incentives and facilitating for new business registrations. This is typically done by streamlining registration and licensing procedures, or by creating a one-stop shop where all registration services may be accessed in one place.

Around the world, reducing the regulatory burden is high on the agenda for policymakers interested in growing entrepreneurial economies. Policymakers are increasingly using the complexity of the regulatory environment as currency to encourage entrepreneurship. An increasingly globalized world means that policymakers have to compete harder to be "more attractive" for business, because of the geographic flexibility available to entrepreneurs. Policymakers can use a wide range of regulatory tools to enhance the business environment, but do not often have enough information to decide among options. For example, should the burden of obtaining licenses be reduced, or should the burden of registering a business be reduced? If one particular type of regulation is chosen for reform, should this be done at the national level? Should policymakers offer incentives or grants to help offset the costs of compliance with national regulations? Should a "one-stop" shop be established to help entrepreneurs complete their important regulatory requirements, such as filing tax and social security paperwork?

The relationship between regulation and entrepreneurship is important from both a scholarly and a policy perspective, as well as from the practitioner's view. Given the importance of entrepreneurship in driving economic growth, and in generating important social and economic welfare gains, the regulatory set-up that governs entrepreneurial endeavours is obviously a decisive factor. While a growing number of studies consider the regulatory environment, especially entry regulation (Stenholm et al., 2013; Klapper et al., 2006), as a driver of entrepreneurship (Ciccone and Papaionnou 2006, Acs et al., 2008; Ardagna and Lusardi 2009, Djankov et al., 2002), the literature on regulations and entrepreneurship is still

\footnotetext{
${ }^{1}$ See Hägg (1997) for a review of economic theories of regulation.
} 
young. In particular, more in-depth examinations that take into account heterogeneity across multiple levels (Audretsch et al., 2013), such as industries, institutions (e.g, courts), regions and countries is necessary, as well as across various types of entrepreneurial outcomes (Stenholm et al., 2013), such as new firm formation or entrepreneurial growth expectations (see Estrin et al., 2013). In addition, the extent of regulation has also been shown to have considerable indirect effects which could influence entry. As shown by Ardagna and Lusardi (2008), the positive effect associated with skills (education) diminishes considerably in more regulated countries, particularly for opportunity-based entrepreneurship.

This paper serves as the introduction to a special issue comprising a set of contributions that are concerned with regulation and entrepreneurship. The intention is to shed light on several important questions likely to be relevant for future research on regulations and entrepreneurship. The remainder of this paper is structured as follows. Next, we provide a brief overview of the literature on regulation along two key perspectives, the public interest view and the special interest view of regulation. In the third section, we discuss the state of current knowledge on regulations and entrepreneurship. We introduce the papers in the special issue in the fourth section, followed by brief conclusion.

\section{Two perspectives on regulation: Public or special interest?}

Economists have long been interested in how to use regulations to correct market failures, or to modify undesirable behaviour or investment activity on part of market actors. Regulations can affect efficiency and distribution of the gains from economic activities, and could be used not only to correct market failures, but also to improve welfare gains from economic activities. In this perspective - the public interest view of regulation - policymakers are assumed to undertake and design regulations for a benevolent and welfare-enhancing purpose (see Pigou, 1938). For example, public utilities and price regulations of monopolies are interventions intended to achieve more efficient resource allocation and improve welfare.

An alternative perspective is represented by the special interest view of regulation, i.e. regulatory regimes are structured and enforced by parties competing for regulatory power who are not acting in the interest of overall social welfare (see Peltzman, 1976; Becker, 1983). The special interest view of regulation is related to the theory of regulatory capture (see Stigler, 1971), and both approaches suggest that regulation is set up as a means to favour 
certain groups. In the special interest view, multiple groups compete for regulatory power and control, whereas in the capture theory of regulation, one dominant actor monopolizes power and decision-making in a regulatory agency. In both contexts, companies in the regulated industries might proactively embed themselves in the regulatory policy process, in order to create better conditions for themselves, such as passing regulations, which serve to erect entry barriers to limit competition. In a capture perspective, one dominant actor emerges whereas in a special interest perspective, multiple actors compete and the consolidation of regulatory power can change. The special interest theory thus implies that regulations would favour some groups. For example, passing of industry regulatory standards or certification requirements could raise costs for potential new firms, thereby discouraging entry (and competition).

\section{Regulations and entrepreneurship}

The economics of regulation spans a wide variety of topics, ranging from macro-oriented growth, allocative efficiency and systemic effects, to issues related to entry, firm growth and cultural aspects. Regulation effects may be classified according to the area that is affected, i,e, the product and factors markets or entry and competition. Alternatively regulations could be separated with regard to their direct and indirect effects. In this section we will briefly refer to some of the findings in previous research regarding the impact of regulation on entry.

A first observation is that regulations are certainly needed in order to secure transparent and efficient markets. That relates in particular to property rights and credible sanctions systems when property rights are violated, i.e. the basic pillars of a rule of law institutional set-up must be present. At the same time there seems to be consensus that to much of regulations may also hinder industrial dynamics, innovations and productivity growth. De- or reregulation may then improve the functioning of an economy, thereby enhancing efficiency and generating higher growth and prosperity (Nicoletti and Scarpetta 2003, Gordon 2004, Djankov 2008).

Second, excessive regulations have been shown to influence entrepreneurship as well as the size of startups, thereby reducing the probability for success since firms enter markets being too small (Ciccone and Papaionnou 2006, Ardagna and Lusardi 2009). ${ }^{2}$ Ciccone and

\footnotetext{
${ }^{2}$ Gordon (2004) and Bosma and Harding (2007) claim that institutional differences explains the growth differences between Europe and the US.
} 
Papaioannou (2006) provide more detailed evidence that entry regulation can delay introduction of new varieties/goods in industries that experience expansionary global demand or where technology shocks open up new business opportunities, thereby deterring growth. Similarly, findings by Aghion et al. (2006) shows that entry - or entry threats - has positive effects on the innovative behavior by incumbent firms close to the technological frontier, while no such effects could be found for technological laggards.

In particular, high start-up costs seems to deter new ventures entering the market (Fonseca et al 2001, 2007, Glaeser and Kerr (2009). Part of these costs refers to high taxes (Gordon 1998, Cullen and Gordon 2007), not only associated with entrepreneurial activities as such, but also through indirect effects linked to the effects of taxes on wealth formation (Evans and Jovanovic 1989, Banerjee and Newman 1993). ${ }^{3}$ In addition, a complex regulatory tax structure may also hamper entrepreneurial entry (Braunerhjelm and Eklund 2014).

Third, even though the evidence are not unambiguous, most studies conclude that factor market regulation negatively impact competition and entry. For instance, Pagès and Micco (2006), Author et al (2007) and Kugler and Pica (2008) all report a significant negative impact on entry of higher regulated labor markets, as well as a slower restructuring of the economy. Similarly, studies on the determinants of foreign direct investments find a negative effects of regulated labor markets (Javorcik et al 2006, Gross and Ryan 2008). In addition, productivity seems to decrease as labor market regulations become more severe (Bassanini and Venn 2007, Martins 2009), and the number of fast growing firms - gazelles - also tend to be negatively influenced.

Fourth, the extent of regulation has interesting indirect effects that influence entry. As shown by Ardagna and Lusardi (2008), the positive effect associated with skills (education) diminishes considerably in more regulated countries, particularly for opportunity-based entrepreneurship. In addition, it significantly reduces the propensity for marginalized groups to start up firms. Similarly, the positive effects of knowing people who are entrepreneurs, run their own firms, i.e. network and belongs to an entrepreneurial culture, is curbed. The results comply with earlier findings of Klapper et al (2006) and also of Ciccone and Papaioannou (2006), referred to above.

\footnotetext{
${ }^{3}$ See Gentry and Hubbard (2000) and Hansson (2008) for the effects of different types of taxes on entry.
} 
Fifth, a number of studies find that more informal rules and regulations, i.e. social norms, do influence entrepreneurship. An obvious indicator of this is the parent effect, that is, the likelihood of becoming a firm-owner or starting a new firm increases if the parents had their own firms (Dunn and Holtz-Eakin 2000, Davidsson and Honig 2003, Gianetti and Simonov 2004). There also seem to be the case that an environment dominated by smaller and independent firms become more conducive to entrepreneurship than environments hosting larger firms (Glaeser et al 2009, Glaeser and Kerr 2009).

Overall there seems to be a delicate balance between providing an institutional envirionment that is conducive to entry and growth, and passing the point where overregulation curbs the potentially large welfare effects related to entrepreneurship and growing firms. Overly regulated economies may thus impede creative destruction, enhanced efficiency, higher productivity and growth (Acemoglu et al. 2003, 2006 and Chun et al., 2007). The challenge for the policy-maker is to provide the right balances between the two forces.

In addition to these direct effects, regulation can affect entry by shaping the conditions in the overall business environment. To illustrate this, we can use some proxy variables. One broad measure, which is available for a large number of countries, is the Doing Business Index. This index measures the quality of business regulations for a broad range of regulatory areas relevant for the business climate in a country, which should provide insight on different conditions which affect firm dynamics.

We use the broadest possible measure which is the over all ranking of the quality of the business environment. Desai and Eklund (2014) provide a measure of how swiftly firm in 44 countries are able to adjust their capital stock to changes in output. This is in de facto a measure of the dynamics of an economy and the ability of firms to adjust their production capacity to changes in supply and demand conditions, and provides a broad measure of how dynamically efficient an economy is (re)allocating resources from sectors with poor prospects to sectors with good investment opportunities. Essentially the method simply measures the elasticity of the capital stock (total assets) with respect to output (sales) (see Desai and Eklund, 2014 for more). 
As can be seen in figure 1 below there is a strong correlation between the dynamic efficiency of firms and the over-all quality of regulations ${ }^{4}$. The data on allocation of capital as a measure of firm dynamics has been collected from Desai and Eklund (2014). Their measure is based on panel of approximately 12,000 firms across 44 countries. Allocation of capital is measured as the elasticity of the capital stock with respect to output, which provides a measure of the dynamic efficacy of the business sector in an economy. The data on new business entry rate was collected from the World Bank. Data used is for 2012.

Further, in figure 2 we can also see that there is a strong correlation between new business entry rate and the over-all quality of regulations.

\section{Figure 1, Firm Dynamics and Business Regulations}

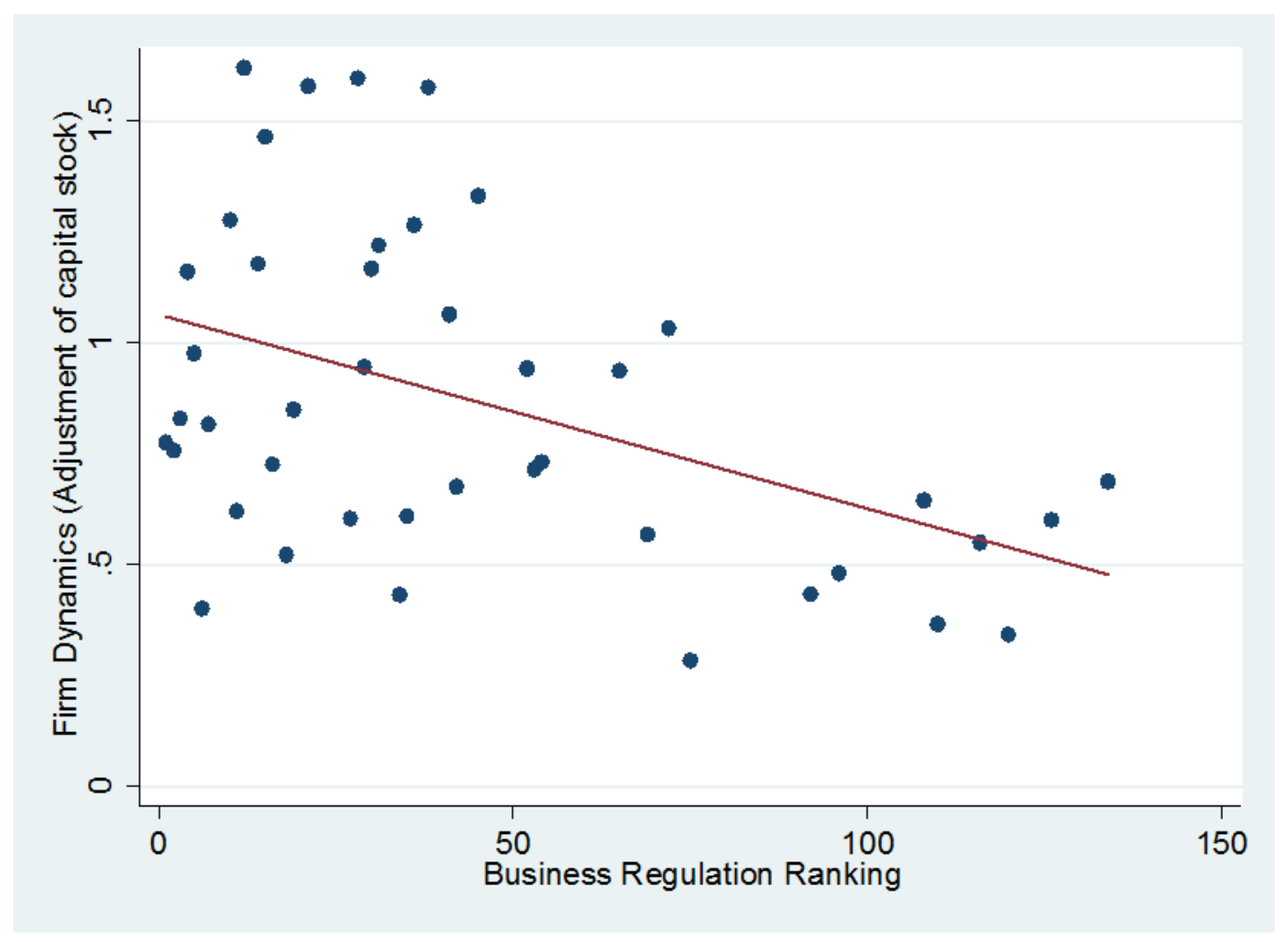

The correlation between firm dynamics and business regulations is -0.45 . The regression line is significant at one present and $\mathrm{R}^{2}$ is 0.28 .

\footnotetext{
${ }^{4}$ As a measure of quality of regulations, we use the overall doing business index. After merging the three data sources we have 43 and 37 observations respectively for new business entry rate and firm dynamics. Norway and Hong Kong were excluded on the basis that observations were four standard deviations from the mean, but keeping them in the data however does not change the results significantly.
} 


\section{Figure 2. New Business Entry Rate and Business Regulations}

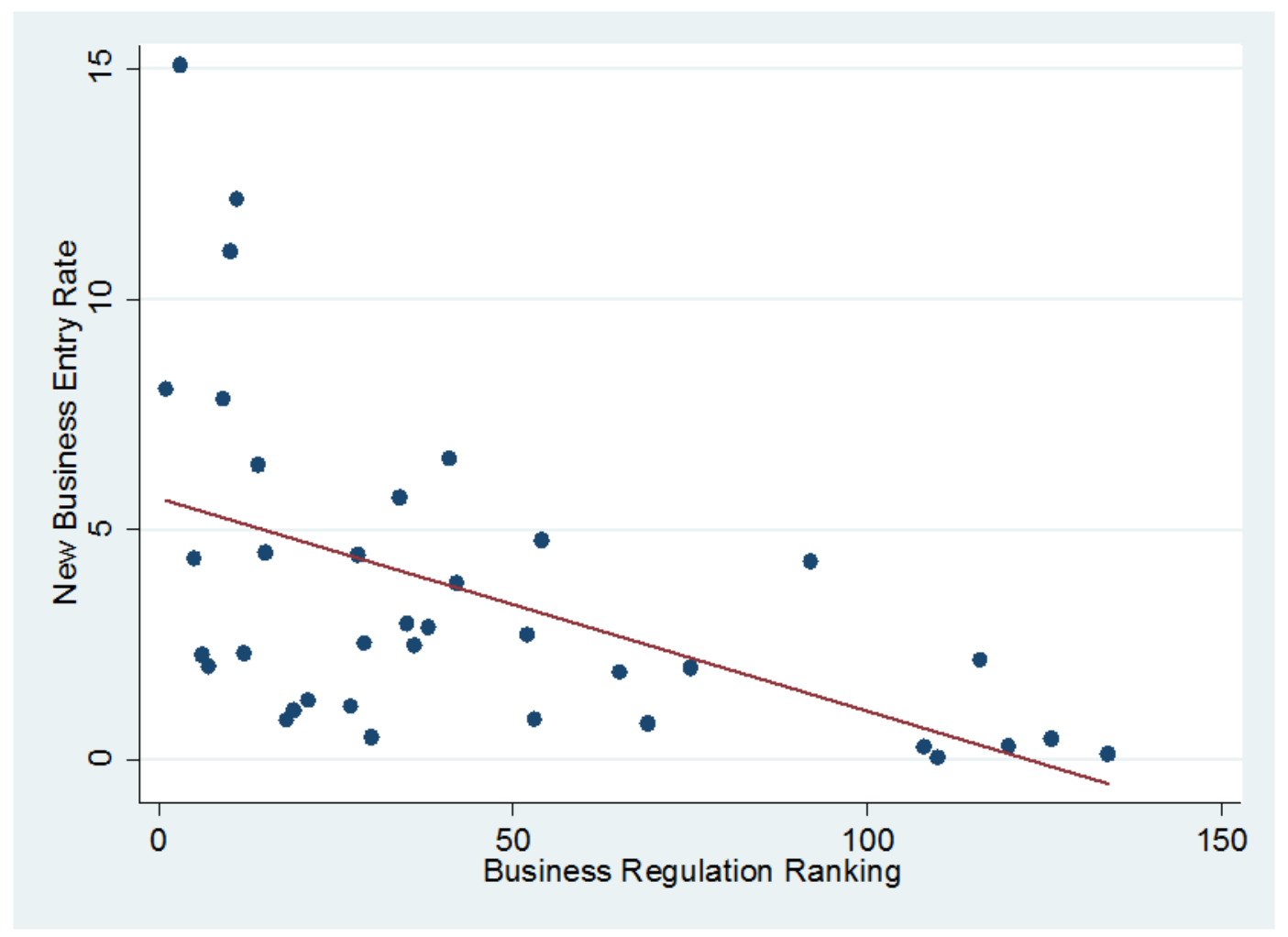

The correlation between firm dynamics and business regulations is -. The regression line is significant at one present and $\mathrm{R}^{2}$ is 0.20 .

Figure 3 displays the relationship between the level of labor market regulations and growth expectations of young start-ups. Again, there seems to be a distinct negative correlation between the regulatory burden and the growth ambitions at the firm level.

Obviously, these correlations do not necessarily reveal any causal link between the quality and the level of regulatory burden and firm dynamics and entrepreneurship. However, they do provide an indication of the importance of more economic research and the links between regulations and their dynamic effects. The papers included in this special issue all contribute to our understanding of how regulations affect economic dynamics and entrepreneurship in different ways. 
Figure 3. Labor market regulations and high-growth-expectation of early-stage entrepreneurship.

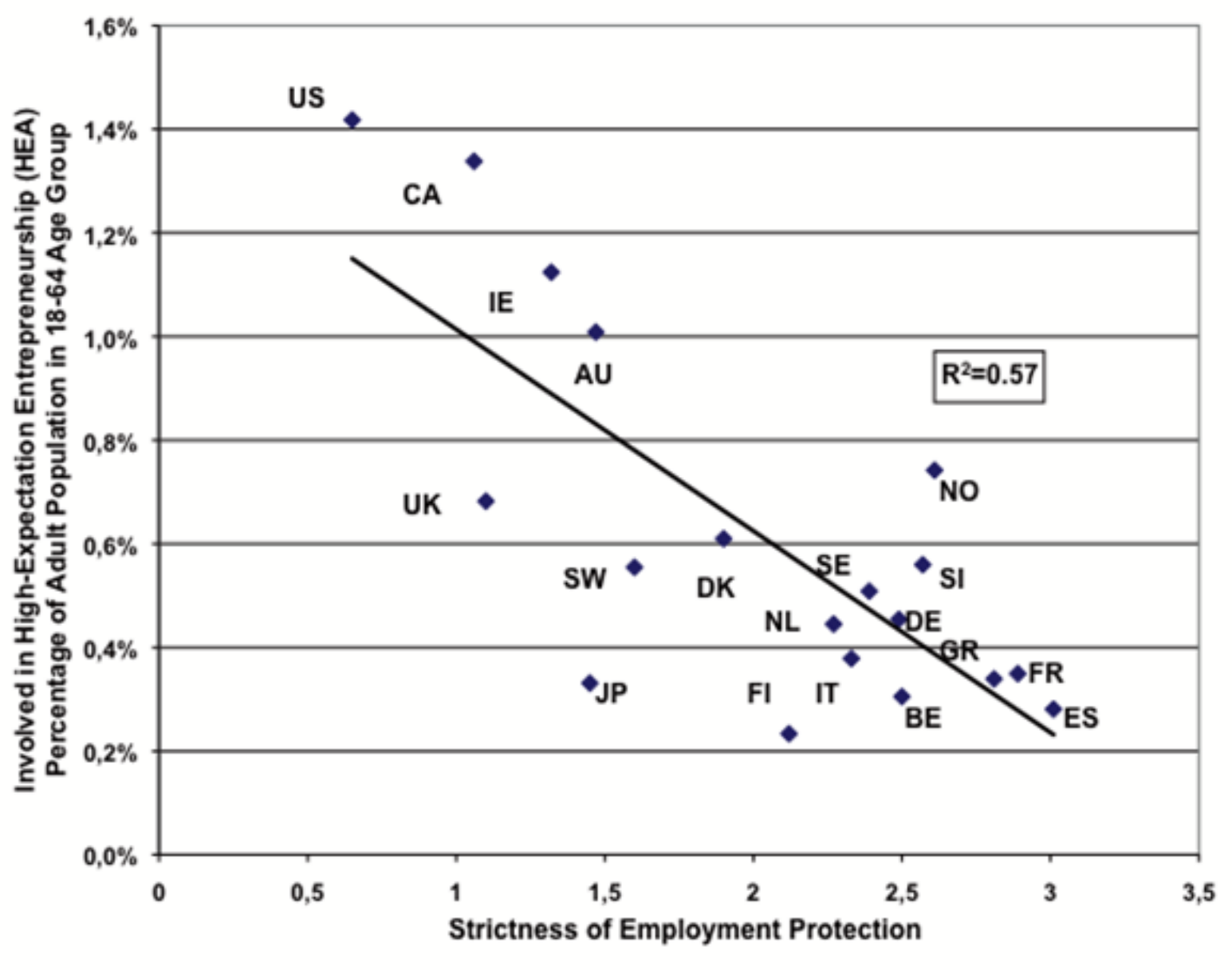

Note: Labor market regulations is taken from OECD index of labor regulations version 2, 2004, high-growth high-expectation early-stage entrepreneurship is an average Global Entrepreneurship Monitor (GEM) 2004-2009.. $\mathrm{R}^{2}=0,57$. Source: Bosma och Levie (2010).

\section{Papers in the special issue}

This special issue contains seven original research articles, which contribute to existing knowledge on regulations and entrepreneurship. Each article has been selected following a peer review process, and most of the articles were initially presented at a workshop sponsored by the Swedish Entrepreneurship Forum on "Regulations, Entrepreneurship and Firm Dynamics", held in Stockholm in August 2013. The special issue is structured to provide insight on different levels and key topics relevant to understanding regulation and entrepreneurship. 
The second paper in the special issue, by Javier Elizalde, Markus Kinateder and Ignacio Rodríguez-Carreño, is titled "Entry Regulation in a Liner Market with Elastic Demand". This paper presents a model conducting a comparative welfare analysis of entry regulation. They examine two types of entry regulation - the number of licenses and the minimum distance between stores. Their analysis demonstrates that heterogeneity of regulatory requirements is an important consideration when disentangling the effects of regulation.

The third paper in the special issue is "Are Bad Times Good News for the Securities and Exchange Comission?" by Tim Lohse and Christian Thomann. The authors examine the relationship between investor protection and stock market development with economic growth and investigate if regulatory efforts are caused by market developments or vice versa. Using funding data from the U.S. Securities and Exchange Commission (SEC) in a timeseries analysis, the authors find a unidirectional relationship where markets determine spending on regulation: A weak market results in greater resources for the SEC and a strong market results in less resources for the SEC.

The remaining papers in the special issue each present a comparative analysis on regulation and entrepreneurship. The fourth paper, "Entrepreneurship and enforcement institutions: Disaggregate evidence from Spain” by Miguel García-Posada and Juan S. Mora-Sanguinetti is an analysis of judicial enforcement institutions and the effect on both entry and exit rates in Spanish provinces. The authors find that greater judicial efficacy is important for entry but not for exit. Their inclusion of exit rates in the study is an important value-added which could prove helpful for future research which extends beyond the study of entrepreneurship and entry, but which begins to ask questions about survival and the quality of entrepreneurial ventures under different regulatory structures.

The fifth paper examines the country level. "Judicial Efficiency and Entrepreneurs' Expectations on the Reliability of the European Legal Systems", by Roberto Ippoliti, Allesandro Melcarne and Giovanni B. Ramello, uses technical efficiency scores of courts (through data envelopment analysis) to explain entrepreneurship. The authors conduct a twostep empirical analysis, first estimating the technical efficiency of courts and second, using technical efficiency scores to explain credit market development and difficulty in enforcing contracts for entrepreneurs. 
Giorgio Calcagnini, Annalisa Ferrando and Germana Giombini co-authored the sixth paper, "Multiple Market Imperfections, Firm Profitability and Investment". Using firm and country level data for eight European countries over the years 1994-2008, the authors investigate the effect of labor, product and financial markets on investment of firms. The findings demonstrate that market regulation hinders profitability. Better access to external funds and higher levels of internal liquidity are found to be positive for investment.

The seventh paper in the special issue, by Farzana Chowdhury, Siri Terjesen and David Audretsch, is titled "Varieties of Entrepreneurship: Institutional Drivers across Entrepreneurial Activity and Country". This paper is a cross-country examination of a wide range of regulatory conditions and three types of entrepreneurship - new firms, nascent entrepreneurship and self-employment. They find that some regulatory conditions, such as property rights protection or human capital, have idiosyncratic impacts on different types of entrepreneurship.

In the last paper, "Institutions, Economic Linearization and Firm Growth: Evidence from European Transition Economies”, Evgeni Peev studies the effects of access to foreign external finance, country governance institutions and economic liberalization on firms in ten European transition economies over the years 1996-2011. The author pays particular attention to joint effects of access to external finance and domestic institutions. The findings of the paper suggest that institutional quality and financial intermediation matter more than the supply of credit, and that access to external finance is more important for firm growth in the presence of weaker country institutions. The author also finds that economic liberalization indirectly affects firm growth through the quality of domestic institutions.

\section{Conclusion}

The purpose of this special issue is to offer several different perspectives across multiple levels of analysis, which highlight the range of questions embedded in the relationship between entrepreneurship and regulation. The literature on regulations and entrepreneurship is young but growing, and is of critical policy and scholarly interest. Each paper advances this literature as well as identifies important next steps for future research. 
Compliance with Ethical Standards

We comply with the ethical standards of the journal. We do not have any conflicts of interest, and no human or animal subjects.

\section{References}

Acemoglu, D., Aghion, P., \& Zilibotti, F. (2003). Vertical integration and distance to frontier. Journal of the European Economic Association, 1(2-3), 630-638.

Acemoglu, D., Aghion, P., \& Zilibotti, F. (2006). Distance to frontier, selection, and economic growth. Journal of the European Economic Association, 4(1), 37-74.

Acs, Z. J., Desai, S., \& Hessels, J. (2008). Entrepreneurship, economic development and institutions. Small Business Economics, 31(3), 219-234.

Aghion, P., Burgess, R., Redding, S., \& Zilibotti, F. (2006). The unequal effects of liberalization: Evidence from dismantling the License Raj in India: National Bureau of Economic Research.

Ardagna, S., \& Lusardi, A. (2008). Explaining international differences in entrepreneurship: The role of individual characteristics and regulatory constraints. in Lerner, J. and Schoar, A. (eds.), International Differences in Entrepreneurship, forthcoming, University Chicago Press.

Ardagna, S., \& Lusardi, A. (2009). Heterogeneity in the Effect of Regulation on Entrepreneurship and Entry Size. NBER WP 15510, NBER. MA. Cambridge.

Audretsch, D. B., \& Walshok, M. (2013). Creating Competitiveness: Entrepreneurship and Innovation Policies for Growth: Edward Elgar Publishing.

Autorm D. H., Kerr, W. R. and Kugler, A. D., (2007), "Does Employment Protection Reduce Productivity? Evidence From US States" Economic Journal, Vol. 117, Issue 521, 189217.

Banerjee, A. V., \& Newman, A. F. (1993). Occupational choice and the process of development. Journal of Political Economy, 274-298.

Bassanini, A., \& Venn, D. (2007). Assessing the impact of labour market policies on productivity: a difference-in-differences approach: OECD Publishing.

Becker, G. S. (1983). A theory of competition among pressure groups for political influence. The Quarterly Journal of Economics, 371-400.

Bosma, N., \& Harding, R. (2007). Global entrepreneurship monitor: GEM 2006 results.

Braunerhjelm, P., \& Eklund, J. E. (2014). Taxes, tax administrative burdens and new firm formation. Kyklos, 67(1), 1-11.

Chun, H.Kim, J.W., Morck, R. \& Yeung, B.. (2007) Creative destruction and firm-specific performance heterogeneity, NBER Working Paper 13011, Cambridge, MA.

Ciccone, A., \& Papaioannou, E. (2006). Red Tape and Delayed Entry. CEPR DP 5996, CEPR, London.

Cullen, J. B., \& Gordon, R. H. (2007). Taxes and entrepreneurial risk-taking: Theory and evidence for the US. Journal of Public Economics, 91(7), 1479-1505.

Davidsson, P., \& Honig, B. (2003). The role of social and human capital among nascent entrepreneurs. Journal of Business Venturing, 18(3), 301-331.

Desai, S., \& Eklund, J. E. (2014). "Ownership and the allocation of capital: Evidence from 44 countries," Journal of Institutional and Theoretical Economics, vol. 170(3), 427-452.

Djankov, S. \& La Porta, R., Lopez-De-Silanes F., \& Shleifer, A. (2002). The Regulation Of Entry, The Quarterly Journal of Economics, MIT Press, vol. 117(1), pages 1-37.

Djankov, S, (2008). The Regulation of Entry: A Survey, CEPR Discussion Papers 7080, C.E.P.R. Discussion Papers. 
Dunn, T., \& Holtz-Eakin, D. (2000). Financial capital, human capital, and the transition to self-employment: Evidence from intergenerational links: National bureau of economic research.

Estrin, S., Korosteleva, J., \& Mickiewicz, T. (2013). Which institutions encourage entrepreneurial growth aspirations? Journal of Business Venturing, 28(4), 564-580.

Evans, D. S., \& Jovanovic, B. (1989). An estimated model of entrepreneurial choice under liquidity constraints. The Journal of Political Economy, 808-827.

Fonseca, R., Michaud, P. \& Sopraseuth, T. (2007). Entrepreneurship, wealth, liquidity constraints, and start-up costs. Comparative Lbor Law and Policy Journal, 28, 637674.

Fonseca, R., Lopez-Garcia, P., \& Pissarides, C. A. (2001). Entrepreneurship, start-up costs and employment. European Economic Review, 45(4), 692-705.

Gentry, W. M., \& Hubbard, R. G. (2000). Tax policy and entrepreneurial entry. American Economic Review, 283-287.

Giannetti, M., \& Simonov, A. (2004). On the determinants of entrepreneurial activity: Social norms, economic environment and individual characteristics. Swedish Economic Policy Review, 11(2), 269-313.

Glaeser, E. L., \& Kerr, W. R. (2009). Local industrial conditions and entrepreneurship: how much of the spatial distribution can we explain? Journal of Economics \& Management Strategy, 18(3), 623-663.

Glaeser, E. L., Resseger, M., \& Tobio, K. (2009). Inequality in Cities Journal of Regional Science, 49(4), 617-646.

Gordon, N. (2004). Do federal grants boost school spending? Evidence from Title I. Journal of Public Economics, 88(9), 1771-1792.

Gordon, R. H. (1998). Can high personal tax rates encourage entrepreneurial activity? Staff Papers-International Monetary Fund, 49-80.

Gross, D. M., \& Ryan, M. (2008). FDI location and size: Does employment protection legislation matter? Regional Science and urban economics, 38(6), 590-605.

Hägg, P. G. (1997). Theories on the Economics of Regulation: A Survey of the Literature from a European Perspective. European Journal of Law and Economics, 4(4), 337370.

Hansson, A. (2008). Income taxes and the probability to become self-employed: The case of Sweden, Ratio Working Papers No. 122.

Javorcik, B., Arnold, J., \& Mattoo, A. (2006). The Productivity Effects of Services Liberalization: Evidence from the Czech Republic. World Bank Policy Research Working Paper.

Klapper, L., Laeven, L., \& Rajan, R. (2006). Entry regulation as a barrier to entrepreneurship. Journal of Financial Economics, 82(3), 591-629.

Kugler, A., \& Pica, G. (2008). Effects of employment protection on worker and job flows: Evidence from the 1990 Italian reform. Labour Economics, 15(1), 78-95.

Martins, A. P. (2009). Union duopoly with heterogeneous labor: the effect of minimum wage regulation. International Journal of Social Economics, 36(5), 580-607.

Nicoletti, G., \& Scarpetta, S. (2003). Regulation, productivity and growth: OECD evidence. Economic policy, 18(36), 9-72.

Pages, C., \& Micco, A. (2006). The economic effects of employment protection laws. Paper presented at the IZA/The World Bank Conference on Employment and Development.

Peltzman, S. (1976). Toward a more general theory of regulation. National Bureau of Economic Research Cambridge, Mass., USA.

Pigou, A. C. (1938). The Economics of Welfare. MacMillian and Co, London

Stenholm, P., Acs, Z. J., \& Wuebker, R. (2013). Exploring country-level institutional 
arrangements on the rate and type of entrepreneurial activity. Journal of Business Venturing, 28(1), 176-193.

Stigler, G. J. (1971). The theory of economic regulation. The Bell journal of economics and management science, 3-21. 